\title{
Does resveratrol preserve the integrity of the sperm membrane in goats after thawing?
}

\section{$O$ resveratrol preserva a integridade da membrana espermática de caprinos após descongelamento?}

\author{
Lindomar Sousa Brito ${ }^{1 *}$; Larissa Pires Barbosa ${ }^{2}$; Alexandre Moraes Pinheiro ${ }^{2}$; Max \\ Vitória Resende ${ }^{3}$; Nariane Gavazza de Lima Costa ${ }^{4}$; William Morais Machado \\ Ronival Dias Lima de Jesus'; ; Márcio de Oliveira Ribeiro4; Caline Santana da \\ França $^{4}$; Reuber de Carvalho Cardoso ${ }^{1}$
}

\section{Highlights:}

The resveratrol was effective in maintaining sperm viability up to $0.039 \mathrm{mg} \mathrm{mL}^{-1}$.

The resveratrol in extender could not preserve progressive sperm motility and vigor.

No significant differences were observed between treatments for acrosomal integrity.

\begin{abstract}
This study aimed to determine the effects of resveratrol in the trisaminomethane (TRIS)-egg yolk extender and its optimal inclusion level for goat semen cryopreservation. Five ejaculates of three Anglo Nubian goats were used, each divided into four $200 \mu \mathrm{L}$ aliquots for use in four treatments: 0.00 (control), $0.04,0.08$ and $0.12 \mathrm{mg} \mathrm{mL}^{-1}$ resveratrol in the TRIS-egg yolk extender. We evaluated progressive sperm motility and sperm vigor post-dilution, post-cooling, and post thawing; membrane integrity (HOST); and acrosomal integrity and performed a slow thermoresistance test (STT). The data were submitted to a regression analysis at a 5\% probability. There was no difference in progressive motility or sperm vigor in the post-dilution $(89.5,89.0,88.7$ and 88.3 , and 4.9, 5.0, 4.9, and 4.9) or post-cooling (81.0, 82.0, 83.0, and 78.3; and 4.3, 4.3, 4.2, and 4.2) experiments $(\mathrm{P}>0.05)$, or in the complementary acrosomal integrity test $(42.0,47.4,42.2$ and 38.2) $(\mathrm{P}>0.05)$. However, the motility and vigor parameters decreased linearly in the post-thaw phase, as well as during the 2 hours of incubation on STT $(\mathrm{P}<0.05)$. These factors increased quadratically when resveratrol was added to HOST, to an optimal level of $0.039 \mathrm{mg}$ $\mathrm{mL}^{-1}$ resveratrol for a plasma membrane integrity of $52.55 \%(\mathrm{P}<0.05)$. The inclusion of resveratrol was effective in maintaining sperm viability; in particular, it was effective in maintaining plasmatic membrane integrity during the cryopreservation process up to $0.039 \mathrm{mg} \mathrm{mL}^{-1}$, meaning that it could be an alternative to conventionally used seminal extenders in goats.
\end{abstract}

Key words: Antioxidants. Oxidative stress. Sperm. TRIS-egg yolk.

\footnotetext{
1 Discentes do Curso de Mestrado do Programa de Pós-Graduação em Ciência Animal, Centro de Ciências Agrárias, Ambientais e Biológicas, CCAAB, Universidade Federal do Recôncavo da Bahia, UFRB, Cruz das Almas, BA, Brasil. E-mail: lindomar. britto@gmail.com; reubercarv@gmail.com

2 Profs. Drs., Departamento de Medicina Veterinária, CCAAB, UFRB, Cruz das Almas, BA, Brasil. E-mail: larissa@ufrb.edu.br; amp@ufrb.edu.br

3 Prof. Dr., Universidade Salvador, UNIFACS, Salvador, BA, Brasil. E-mail: maxvresende@gmail.com

4 Discentes do Curso de Graduação em Medicina Veterinária, CCAAB, UFRB, Cruz das Almas, BA, Brasil. E-mail: nariane. gavazza@gmail.com; william.moraiss@hotmail.com; ronydias_19@hotmail.com; francacs@outlook.com; big16fsa@hotmail. com

* Author for correspondence
} 


\section{Resumo}

O objetivo deste estudo foi determinar os efeitos e o melhor nível de inclusão de resveratrol em meio diluidor TRIS gema de ovo para criopreservação de sêmen caprino. Foram utilizados cinco ejaculados de três bodes da raça Anglo Nubiana. Cada ejaculado foi dividido em quatro alíquotas de $200 \mu \mathrm{L}$, compondo quatro tratamentos: 0,00 (controle); 0,$04 ; 0,08$ e $0,12 \mathrm{mg} \mathrm{mL}^{-1}$ de resveratrol no diluidor TRIS gema de ovo. Foram avaliadas a motilidade espermática progressiva e o vigor espermático pósdiluição, pós-resfriamento e pós-descongelamento; integridade de membrana (HOST); integridade acrossomal e teste de termorresistência lento (TTR). Os dados foram submetidos à análise de regressão a $5 \%$ de probabilidade. Não houve diferença para a motilidade progressiva e o vigor espermático, respectivamente, na pós-diluição $(89,5 ; 89,0 ; 88,7$ e 88,3$)$ e $(4,9 ; 5,0 ; 4,9$ e 4,9$)$ e pós-resfriamento $(81,0 ; 82,0 ; 83,0$ e 78,3$)$ e $(4,3 ; 4,3 ; 4,2$ e 4,2$)(\mathrm{P}<0,05)$, assim como para o teste complementar integridade acrossomal $(42,0 ; 47,4 ; 42,2$ e 38,2$)(\mathrm{P}>0,05)$. No entanto, os parâmetros motilidade e vigor reduziram linearmente no pós-descongelamento, assim como durante as 2 horas de incubação no TTR $(\mathrm{P}<0,05)$. Houve efeito quadrático com a inclusão de resveratrol para HOST, apresentando um nível ótimo de $0,039 \mathrm{mg} \mathrm{mL}^{-1}$ de resveratrol para integridade de membrana plasmática de $52,55 \%(\mathrm{P}<$ $0,05)$. A inclusão de resveratrol foi eficiente na manutenção da viabilidade espermática; em especial, foi eficiente na manutenção da integridade da membrana plasmática durante o processo de criopreservação até o nível de $0,039 \mathrm{mg} \mathrm{mL}^{-1}$, podendo ser uma alternativa na composição dos diluidores seminais de caprinos.

Palavras-chave: Antioxidantes. Espermatozoide. Estresse oxidativo. TRIS gema de ovo.

\section{Introduction}

As well as playing a key role in limiting the spread of sexually transmitted diseases, cryopreserved semen has become fundamental to artificial insemination and genetic material dissemination. However, thermic shock, i.e., the thawing process, is known to cause damage to sperm (Bucak et al., 2009). High levels of reactive oxygen species (ROS), such as hydrogen peroxide $\left(\mathrm{H}_{2} \mathrm{O}_{2}\right)$ and superoxide radical anion $\left(\mathrm{O}_{2}^{\bullet-}\right)$, are produced during the cryopreservation process (Sicherle, Maia, Bicudo, Rodello, \& Gallego, 2011).

Despite the benefits of ROS production in triggering the biochemical events of capacitation and acrosome reactions (Peris, Bilodeau, Dufour, \& Bailey, 2007), an imbalance between reactive species and antioxidant defenses in the cells leads to oxidative stress, which may be responsible for the sperm motility reduction, lipid peroxidation (LPO), and DNA fragmentation observed after semen thaws (Brito et al., 2017; Santiani et al., 2014). Although spermatozoa with compromised
DNA integrity are capable of fertilizing oocytes, the embryos produced could have abnormal growth (Agarwal \& Allamaneni, 2004).

For this reason, researchers have been testing multiple antioxidant substances such as resveratrol (3, 5, 4'-trihydroxystilbene), a non-flavonoid polyphenolic compound mainly found in grapes and vines, in diluted environments. Some studies have shown that resveratrol preserves the membrane and DNA of sperm in some mammals, such as humans (Garcez, Branco, Lara, Pasqualotto, \& Salvador, 2010), goats (Stojanović, Sprinz, \& Brede, 2001), sheep (Sarlós, Molnár, Kókai, Gábor, \& Rátky, 2002; Silva, Cajueiro, Silva, Soares, \& Guerra, 2012), and buffalo (Longobardi et al., 2017). However, Silva et al. (2012) did not observe significant improvements in sperm parameters post-thawing in ovine semen samples treated with resveratrol.

We hypothesized that adding resveratrol to the seminal extender before cryopreservation would improve caprine sperm quality through its antioxidant action. Therefore, our objective was to 
evaluate and compare in vitro the optimal resveratrol inclusion levels on the extender environment to preserve the physical and morphological features of goat semen during cryopreservation.

\section{Material and Methods}

\section{Ethics statement}

This study was approved by the ethics committee of the FederalUniversity ofBahia Reconcavo(CEUA - UFRB) (process number 23007.005461/2014-18).

\section{Animals and study location}

The experiment was performed in the city of Cruz das Almas-BA, located at $12^{\circ} 39^{\prime} 54^{\prime \prime} \mathrm{S}, 39^{\circ} 04^{\prime} 44^{\prime \prime}$ $\mathrm{W}$, and an altitude of $220 \mathrm{~m}$. The region has an average annual rainfall of $1,224.00 \mathrm{~mm}$ and a warm, humid tropical climate; the average temperature and relative humidity are $24.5^{\circ} \mathrm{C}$ and $80 \%$, respectively, (classification Köppen). Three Anglo Nubian breeders were used, between two and three years old, with an average body condition equal to $3 \pm 0.3$ (1 to 5 scale), according to the methodology of Cézar and Sousa (2006). The animals were considered clinically healthy and reproductively able according to the andrological examination standards of the Brazilian Council of Animal Reproduction (Henry, Neves, \& Jobim, 2013). The animals were kept under a semi-intensive production regimen, with access to a pasture of Brachiaria decumbens, and their diet was supplemented with a protein concentrate of 800 $\mathrm{g}_{\text {animal }}{ }^{-1}$ (Nutrividas $^{\mathrm{TM}}$ ) daily, mineral salt, and ad libitum water.

\section{Semen collection and processing}

Semen collection was performed twice each week using the artificial vagina method in the presence of a goat in estrus as a mannequin; five viable ejaculates were collected for each animal. After collection, the ejaculates were brought to the lab, packed in a water bath at $32{ }^{\circ} \mathrm{C}$ and submitted to physical and morphological examination for volume, color, odor, aspect, mass motility, progressive motility, vigor, and concentration, according to Henry et al. (2013) guidelines. Only the samples that met the minimum recommended standards (sperm motility $\geq 70 \%$, mass motility $\geq 4$, vigor $\geq 3$, normal sperm $\geq 80 \%$, and major defects $\leq 10 \%$ ) were referred to the cryopreservation process (Henry et al., 2013). After evaluation, each ejaculate was divided into four $200 \mu \mathrm{L}$ aliquots and diluted using the TRISegg yolk extender (Resende \& Weitze, 1987) for use in four treatments: 0.00 (control), 0.04, 0.08, and $0.12 \mathrm{mg} \mathrm{mL}^{-1}$ of resveratrol, respectively, determined according to the methodology proposed by Silva et al. (2012). The semen was diluted using the method of Brito et al. (2017) to show 100-120 million spermatozoa per dose.

\section{Cryopreservation and sperm analysis}

The cryopreservation process comprised two steps. In the first step, referring to the positive curve, the tubes with liquid semen were put in aluminum mugs $(140 \mathrm{~mm}$ high $\times 60 \mathrm{~mm}$ in diameter), containing $300 \mathrm{~mL}$ of water at $32{ }^{\circ} \mathrm{C}$. The aluminum mugs were placed in a refrigeration system comprising a thermic box with a capacity of $11 \mathrm{~L} \mathrm{(360} \mathrm{mm} \mathrm{x} 265 \mathrm{~mm} \times 240 \mathrm{~mm}$ in length, width, and height, respectively) filled with $4.5 \times 10^{-3}$ $\mathrm{m}^{3}$ of water in ice cube form. This system created a cooling curve of $-0.2{ }^{\circ} \mathrm{C} \mathrm{min}{ }^{-1}$, achieving a balance of $5{ }^{\circ} \mathrm{C}$ at 3 hours. The second step referred to the negative curve. The semen was packaged in straw $(0.25 \mathrm{~mL})$, sealed with non-toxic modeling mass and subjected to nitrogen vapor during 15 minutes, followed by immersion in liquid nitrogen and cryogenic cylinder storage.

The progressive sperm motility and sperm vigor of each treatment were analyzed post-dilution, postcooling, and post-thawing under phase-contrast microscopy (Nikon ${ }^{\mathrm{TM}}$ E200; obj. 20 and 40x). The evaluations of plasmatic membrane integrity (HOST) were performed according to Bittencourt et 
al. (2005). The evaluations of acrosomal integrity were performed according to Pope, Zhang and Dresser (1991). A slow thermoresistance test (STT) was performed according to Henry et al. (2013). Only the samples that presented progressive motility greater than or equal to $30 \%$ and a sperm vigor greater than or equal to two post-thawing were considered for this study.

\section{Statistical analysis}

The experimental design used was completely randomized, with four treatments and fifteen repetitions. Statistical analysis was performed using the command PROC GLM in the statistical program (Statistical Analysis System Institute [SAS Institute], 2003), and the data were submitted for regression analysis, adopting the significance level of $5 \%$. Polynomial contrasts were used to determine the linear and quadratic effects of the treatments.

\section{Results and Discussion}

Including resveratrol in the extender environment did not affect progressive sperm motility or the sperm vigor of the post-diluted and post-cooling semen $(P>0.05)$ (Table 1). However, there was a decreasing linear behavior post-thawing $(\mathrm{P}<0.05)$. (Table 1 and Figures 1a and $1 \mathrm{~b}$ ). The addition of different concentrations resveratrol to the TRIS-egg yolk extender failed to protect the progressive sperm motility and the sperm vigor for all levels tested, with negative effects quality of goat spermatozoa post-thawing. These results are consistent with a previous study that observe significant reduced in sperm parameters post-thawing in ovine semen samples treated with different concentrations of resveratrol (5, 10, 15 e $20 \mu \mathrm{g} \mathrm{mL}-1)$ (Silva et al., 2012).

Table 1

Sperm progressive motility and vigor at post-dilution, post-cooling and post-thawing semen in extender supplemented with resveratrol

\begin{tabular}{|c|c|c|c|c|c|c|c|}
\hline \multirow{2}{*}{ Item } & \multicolumn{4}{|c|}{ Level of inclusion $\left(\mathrm{mg} \mathrm{mL}^{-1}\right)$} & \multirow{2}{*}{ SEM $^{\mathrm{a}}$} & \multicolumn{2}{|c|}{ Significance } \\
\hline & 0 & 0.04 & 0.08 & 0.12 & & $\operatorname{Lin}^{\mathrm{b}}$ & Quad $^{c}$ \\
\hline \multicolumn{8}{|l|}{ Motility (\%) } \\
\hline Post-dilution & $89.5 \pm 3.1$ & $89.0 \pm 2.8$ & $88.7 \pm 3.3$ & $88.3 \pm 3.1$ & 0.77 & 0.260 & 0.898 \\
\hline Post-cooling & $81.0 \pm 5.7$ & $82.0 \pm 5.6$ & $80.3 \pm 4.0$ & $78.3 \pm 5.2$ & 0.05 & 0.112 & 0.268 \\
\hline Post-thawing & $69.0 \pm 6.6$ & $70.7 \pm 7.0$ & $66.7 \pm 10.3$ & $62.3 \pm 9.4$ & 1.33 & 0.017 & 0.176 \\
\hline \multicolumn{8}{|l|}{ Vigor } \\
\hline Post-dilution & $4.9 \pm 0.2$ & $5.0 \pm 0.1$ & $4.9 \pm 0.2$ & $4.9 \pm 0.2$ & 0.13 & 0.433 & 0.725 \\
\hline Post-cooling & $4.3 \pm 0.5$ & $4.3 \pm 0.4$ & $4.2 \pm 0.5$ & $4.2 \pm 0.5$ & 2.15 & 0.382 & 0.695 \\
\hline Post-thawing & $4.0 \pm 0.4$ & $4.0 \pm 0.3$ & $3.8 \pm 0.2$ & $3.7 \pm 0.3$ & 0.08 & 0.022 & 0.529 \\
\hline \multicolumn{8}{|c|}{ Regression equation } \\
\hline \multicolumn{3}{|c|}{ Motility at post-thawing } & \multicolumn{5}{|c|}{$* \hat{\mathrm{Y}}=-60 \mathrm{x}+70.767\left(\mathrm{R}^{2}=0.734\right)$} \\
\hline \multicolumn{3}{|c|}{ Vigor at post-thawing } & \multicolumn{5}{|c|}{$* \hat{\mathrm{Y}}=-1.9744 \mathrm{x}+3.983\left(\mathrm{R}^{2}=0.973\right)$} \\
\hline
\end{tabular}

Average \pm Standard Deviation; ${ }^{a}$ Standard error of mean (\%); ${ }^{b}$ significance for linear effect; ${ }^{c}$ significance for quadratic effect.

*The data were analyzed by regression at $5 \%$ probability. 
These results corroborate those presented by Collodel et al. (2011), who investigated the cytotoxicity of resveratrol in human spermatozoa and mice germ cells. They concluded that progressive sperm motility increased with up to $3.0 \mathrm{mg} \mathrm{mL}^{-1}$ of resveratrol, which acted as an ROS cleaning agent, but after $22.824 \mathrm{mg} \mathrm{mL}^{-1}$, it was totally lethal to sperm cells, so that the DL 50 of these species was $11.412 \mathrm{mg} \mathrm{mL}^{-1}$. However, a study by Aitken et al. (2016), showed that polyphenols in particular, except resveratrol, genistein, and THP $\left(2,2^{\prime}, 4,4^{\prime}\right.$-tetrahydroxydiphenyl) at doses below 100 $\mu \mathrm{M}$, may work as pro-oxidants or alkylating agents in spermatozoa, thereby decreasing their biological competence.

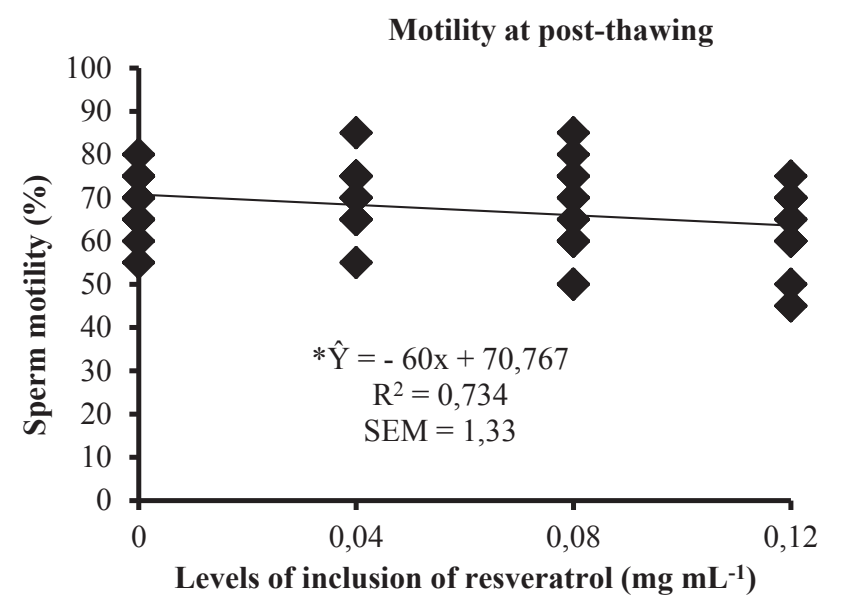

(a)

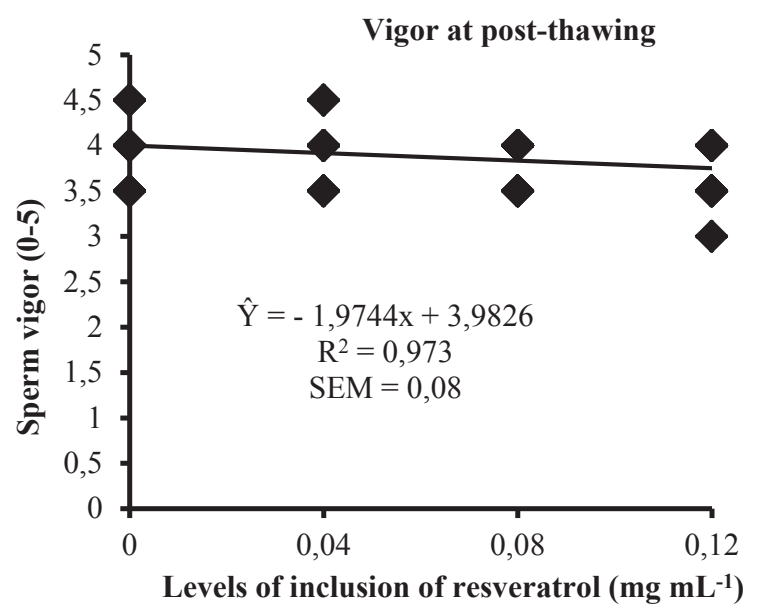

(b)

Figure 1. Regression equation values of semen in extender supplemented with resveratrol post-thaw: (Figure 1a) progressive motility. (Figure 1b) sperm vigor.

Although further studies are necessary, it can be inferred that the concentrations of resveratrol used in to the TRIS-egg yolk extender this study are still high for the Anglo Nubian goats. However, the values of all the characteristics studied were above the minimum limits recommended by Henry et al. (2013) for post-thawing semen, even in the presence of undesirable resveratrol levels.

There was no difference $(\mathrm{P}>0.05)$ in acrosomal integrity between resveratrol treatments 
of cryopreserved semen. However, plasmatic membrane integrity did exhibit a quadratic behavior (HOST) that presented an optimum level of 0.039 $\mathrm{mg} \mathrm{mL} \mathrm{m}^{-1}$ of resveratrol to a HOST of $52.55 \%(\mathrm{P}$ $<0.05$ ) (Table 2 and Figure 2) due to antioxidant inclusion. Therefore, extenders supplemented with resveratrol could reduce the post-thaw spermatozoa damage induced by oxidative stress, as the plasmatic membrane integrity of the goat spermatozoa postthawing. Furthermore, the ROS detoxification mechanisms are related to the capacity of antioxidant agents to control superoxide and nitrite anions, binding to a peroxide radical and/or $\mathrm{OH}^{\bullet}$ - by donating the hydrogen electron from its hydroxyl groups (Kasdallah-Grissa et al., 2007). Resveratrol presence can also reduce lipid peroxidation (LPO) since, besides acting directly on the control of ROS, it also modulates enzymatic antioxidant defense, for instance, to prevent the reduction of SOD, CAT and GPx activities (Ourique et al., 2013; Longobardi et al., 2017).

\section{Table 2}

Acrosomal integrity and HOST of goat semen cryopreserved in extender supplemented with resveratrol

\begin{tabular}{lccccccc}
\hline \multirow{2}{*}{ Item } & \multicolumn{4}{c}{ Level of inclusion $\left(\mathrm{mg} \mathrm{mL}^{-1}\right)$} & \multirow{2}{*}{ SEM $^{\mathrm{a}}$} & \multicolumn{2}{c}{ Significance } \\
\cline { 2 - 5 } & 0 & 0.04 & 0.08 & 0.12 & & Lin $^{\mathrm{b}}$ & Quad $^{\mathrm{c}}$ \\
\hline Int. Acrosomal (\%) & $42.0 \pm 12.3$ & $47.4 \pm 11.7$ & $42.2 \pm 14.1$ & $38.2 \pm 13.5$ & 3.41 & 0.271 & 0.165 \\
HOST (\%) & $47.9 \pm 12.2$ & $55.9 \pm 12.5$ & $45.5 \pm 16.1$ & $39.1 \pm 12.0$ & 3.33 & 0.020 & 0.041 \\
\hline \multicolumn{6}{c}{ Regression equation } \\
\hline HOST & $* \hat{\mathrm{Y}}=-2250 \mathrm{x}^{2}+177.67 \mathrm{x}+49.04\left(\mathrm{R}^{2}=0.831\right)$ \\
\hline
\end{tabular}

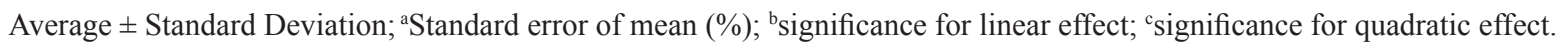

*The data were analyzed by regression at $5 \%$ probability.

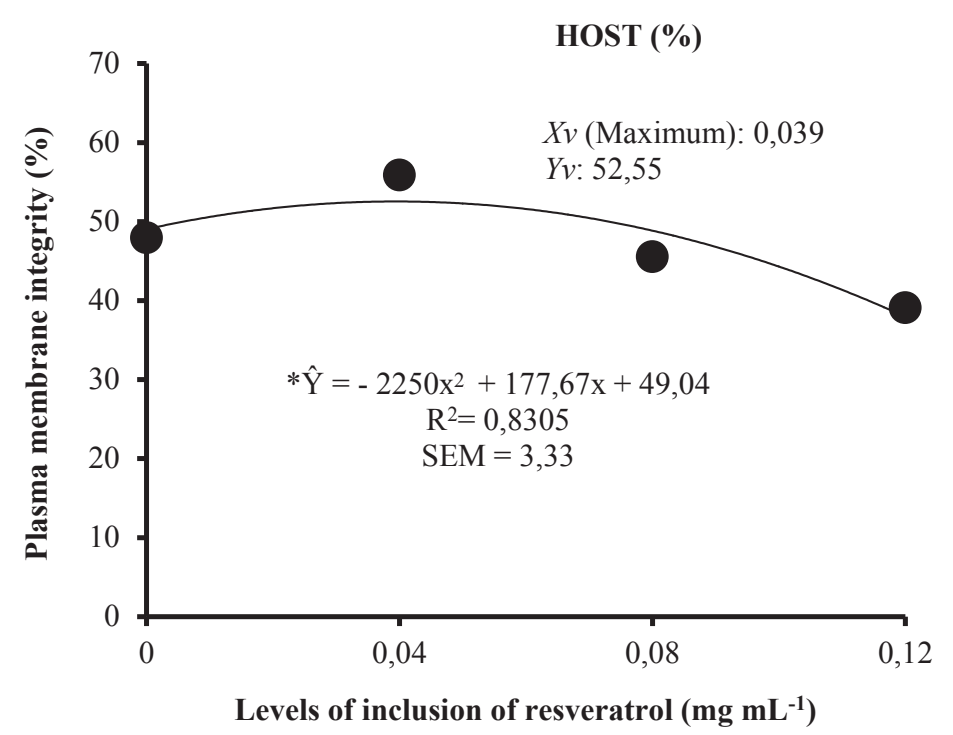

Figure 2. Percentage of spermatozoa with intact plasma membrane in TRIS-egg yolk extender with different levels of resveratrol post-thawing. 
It is noteworthy that resveratrol is described as a potent oxidant that stops ROS formation through two routes: enzymatic systems and non-enzymatic systems. Furthermore, (nicotinamide adenine dinucleotide) NADPH oxidase is especially good at stopping ROS formation, depending on the NADH oxidoreductase (Delmas, Jannin, \& Latruffe, 2005), found on the spermatozoa's plasmatic membrane and mitochondria (Guerra, Evans, \& Maxwell, 2004; Nickel, Kohlhaas, \& Maack, 2014). Additionally, the polyphenols, being amphipathic molecules, can be easily incorporated into the lipid bilayer of the sperm membrane. Consequently, the polyphenols prevent lipid radicals from forming and maintain membrane integrity, as well as the ionic balance of the cells (Garcez et al., 2010; Sarlós et al., 2002), and this confirms that those antioxidants are efficient at containing oxidative damage caused by goat semen cryopreservation.

Moreover, the antioxidant action of resveratrol appeared to reduce enzyme activities that had a role in ROS production or increased activity of the enzyme that metabolizes ROS, such as superoxide dismutase (SOD) (Carrizzo et al., 2013; Longobardi et al., 2017). However, resveratrol may behave as either an antioxidant or a pro-oxidant, since SOD is responsible for $\mathrm{O}_{2}{ }^{-}$- conversion to $\mathrm{H}_{2} \mathrm{O}_{2}$. Therefore, it is assumed that the latter is directly related to cytotoxicity through resveratrol accumulation in the mitochondria (Sassi et al., 2014). This assumption is based on the fact that CAT and GPx saturation may lead to excessive $\mathrm{H}_{2} \mathrm{O}_{2}$ availability, which, in turn, generates $\mathrm{OH}^{\bullet}$, resulting in LPO initiation and propagation (Schmatz et al., 2012).

Considering the context, it is worth highlighting the importance of evaluating sperm membrane integrity, since the injuries to the spermatozoa, especially thermal shock by oxygen contact during semen manipulation, osmotic stress, cryoprotectant toxicity, and the formation and dissolution of crystals in the extracellularenvironment damage spermatozoa irreversibly (Watson, 2000). According to Kao et al. (2008), one of the most important consequences of defective spermatozoa is oxidative stress, because they are ROS-productive cells and can induce LPO as well as DNA fragmentation of viable cells, which can contribute to sperm kinetic reduction (Ourique et al., 2013). In addition, cryopreservation can induce axonemal and mitochondrial damage, resulting in a decrease in sperm motility, since the axoneme present in the middle part of the spermatozoa is surrounded by dense outer fibers that are covered by energy precursor organelles responsible for sperm movement (Memon et al., 2012). Thus, the more cells without mitochondrial activity, the less ATP is produced, meaning less energy for sperm motility, which is one of the main factors contributing to male fertility (Shamsi et al., 2008). Although resveratrol was shown to be capable of preserving plasmatic membrane integrity, possibly by preventing lipid oxidative damage, it was not effective in preventing loss of motility and sperm vigor post-thawing. This behavior may be connected to antioxidant action by the resveratrol, which is a COX-1 specific inhibitor, i.e., an enzyme involved in the synthesis of E-2 series prostaglandins, which are positively correlated to sperm motility (Kennedy, Korn, \& Thurston, 2003).

After two hours of incubation, viable progressive sperm motility and sperm vigor showed negative linear behavior during STT $(\mathrm{P}<0.05)$ (Table 3). According to Purdy (2006), semen cryopreservation promotes motility reduction and lethal damage to spermatozoa. Thus, sperm resistance is reduced, and, when submitted to STT stress, cellular behavior is much more evident. Additionally, dead spermatozoon percentage grows as energy reserves are depleted so that there is higher ROS production and, therefore, more peroxidative damage and lower sperm viability. However, a recent study reported that this test has no correlation with bovine sperm fertility (Talini et al., 2019).

In prior study, Xiang et al. (2014) verified biological activity observed in red wine and resveratrol in isolation and concluded that polyphenol groups gave both substances antioxidant 
potential. Moreover, prior work has shown that the spermatozoa can be protected during freezing by the resveratrol, because it prevents damage to the plasma membrane and DNA induced by spermatozoa cryopreservation in some animals: goats (Stojanović et al., 2001), sheep (Silva et al., 2012), and buffalo (Longobardi et al., 2017).
However, it is important to stress that more studies are required to establish ideal concentrations and effectively determine the antioxidant potential of resveratrol since, in this study, it was observed that this substance yields multiple results, with lower doses improving cellular survival, and higher doses spermatozoon death.

Table 3

Sperm progressive motility (\%) and vigor of goat semen thawed in extender supplemented with resveratrol and subjected to the slow thermoresistance test (STT)

\begin{tabular}{|c|c|c|c|c|c|c|c|}
\hline \multirow{2}{*}{ Item } & \multicolumn{4}{|c|}{ Inclusion levels $\left(\mathrm{mg} \mathrm{mL}^{-1}\right)$} & \multirow{2}{*}{ SEM $^{a}$} & \multicolumn{2}{|c|}{ Significance } \\
\hline & 0 & 0.04 & 0.08 & 0.12 & & $\operatorname{Lin}^{\mathrm{b}}$ & Quad $^{c}$ \\
\hline \multicolumn{8}{|c|}{ Motility (\%) } \\
\hline $0 \mathrm{~min}$ & $69.0 \pm 6.6$ & $71.7 \pm 5.6$ & $68.0 \pm 8.8$ & $64.7 \pm 9.2$ & 1.95 & \multirow{5}{*}{0.043} & \multirow{5}{*}{0.183} \\
\hline $5 \mathrm{~min}$ & $66.3 \pm 7.4$ & $69.7 \pm 5.8$ & $65.7 \pm 8.8$ & $63.0 \pm 10.0$ & 2.07 & & \\
\hline $30 \mathrm{~min}$ & $62.0 \pm 7.3$ & $65.3 \pm 4.4$ & $60.0 \pm 7.1$ & $58.0 \pm 9.0$ & 1.79 & & \\
\hline $60 \mathrm{~min}$ & $59.7 \pm 8.5$ & $61.7 \pm 6.5$ & $56.0 \pm 8.9$ & $51.7 \pm 11.0$ & 2.25 & & \\
\hline $120 \mathrm{~min}$ & $45.0 \pm 13.9$ & $50.3 \pm 19.2$ & $40.7 \pm 18.5$ & $39.3 \pm 17.6$ & 4.47 & & \\
\hline \multicolumn{8}{|l|}{ Vigor } \\
\hline $0 \mathrm{~min}$ & $4.0 \pm 0.3$ & $4.1 \pm 0.3$ & $3.9 \pm 0.3$ & $3.8 \pm 0.4$ & 0.08 & \multirow{5}{*}{0.005} & \multirow{5}{*}{0.441} \\
\hline $5 \mathrm{~min}$ & $3.8 \pm 0.2$ & $3.9 \pm 0.2$ & $3.7 \pm 0.2$ & $3.7 \pm 0.4$ & 0.07 & & \\
\hline $30 \mathrm{~min}$ & $3.7 \pm 0.4$ & $3.8 \pm 0.2$ & $3.6 \pm 0.3$ & $3.5 \pm 0.4$ & 0.08 & & \\
\hline $60 \mathrm{~min}$ & $3.6 \pm 0.4$ & $3.6 \pm 0.4$ & $3.4 \pm 0.3$ & $3.2 \pm 0.4$ & 0.10 & & \\
\hline $120 \mathrm{~min}$ & $3.1 \pm 0.4$ & $3.3 \pm 0.3$ & $2.8 \pm 0.5$ & $2.9 \pm 0.7$ & 0.12 & & \\
\hline \multicolumn{8}{|c|}{ Regression equation } \\
\hline \multicolumn{4}{|c|}{ Motility at post-thawing } & \multicolumn{4}{|c|}{$* \hat{Y}=-52.167 x+62.513\left(R^{2}=0.570\right)$} \\
\hline \multicolumn{4}{|c|}{ Vigor at post-thawing } & \multicolumn{4}{|c|}{$* \hat{Y}=-2.383 x+3.721\left(R^{2}=0.730\right)$} \\
\hline
\end{tabular}

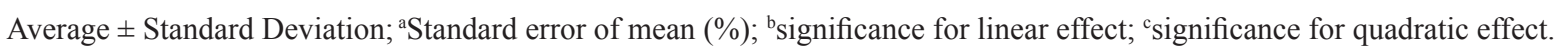

*The data were analyzed by regression at $5 \%$ probability.

\section{Conclusion}

The resveratrol did not prevent the progressive losses in sperm motility or sperm vigor postthawing; however, it was efficient in maintaining the plasma membrane integrity of goat spermatozoa up to $0.04 \mathrm{mg} \mathrm{mL}^{-1}$, presenting an optimum level of $0.039 \mathrm{mg} \mathrm{mL}^{-1}$ of resveratrol in the TRIS-egg yolk extender. Therefore, the results of this study indicated that the ideal concentration of resveratrol, to be used in the TRIS-egg yolk diluent for freezing goat semen, is $0.039 \mathrm{mg} \mathrm{mL}^{-1}$, with no detrimental effects on post-thaw plasma membrane integrity.

\section{Acknowledgements}

The authors thank personnel from UFRB experimental farm (Cruz das Almas, BA, Brazil) for technical support and animal handling, and Prof ${ }^{a}$. Dra . Fabiana Lana for statistical support. 


\section{Conflict of interest}

This research did not receive any specific grants from funding agencies in the public, commercial, or not-for-profit sectors. Therefore, the authors declare that they have no conflicts of interest.

\section{References}

Agarwal, A., \& Allamaneni, S. S. R. (2004). The effect of sperm DNA damage on assisted reproduction outcomes. A review. Minerva Ginecologica, 56(3), 235-245. Recovered from: https://pubmed.ncbi.nlm. nih.gov/15258535/

Aitken, R. J., Muscio, L., Whiting, S., Connaughton, H. S., Fraser, B. A., Nixon, B.,... De Iuliis, G. N. (2016). Analysis of the effects of polyphenols on human spermatozoa reveals unexpected impacts on mitochondrial membrane potential, oxidative stress and DNA integrity; implications for assisted reproductive technology. Biochemical Pharmacology, 121(1), 78-96. doi: 10.1016/j. bcp.2016.09.015

Bittencourt, R. F., Ribeiro, A. L. Fo, Santos, A. D. F., Chalhoub, M., Alves, S. G. G., Vasconcelos, M. F.,... Guimarães, J. D. (2005). Utilização do teste hiposmótico para avaliar a eficácia de diferentes protocolos de criopreservação do sêmen caprino. Ciência Animal Brasileira, 6(3), 213-218. Recovered from: https://www.revistas.ufg.br/vet/article/ view/362

Brito, L. S., Barbosa, L. P., Resende, M. V., Pinheiro, A. M., França, C. S., \& Cardoso, R. C. (2017). Ácido ascórbico no diluidor para criopreservação de sêmen caprino. Ciência Animal Brasileira, 18(1-10), e-40117. doi: 10.1590/1089-6891v18e-40117

Bucak, M. N., Tuncer, P. B., Sariozkan, S., Ulutas, P. A., Coyan, K., Baspinar, N., \& Ozkalp, B. (2009). Effects of hypotaurine, cysteamine and aminoacids solution on post-thaw microscopic and oxidative stress parameters of Angora goat semen. Research in Veterinary Science, 87(3), 468-472. doi: 10.1016/ j.rvsc.2009.04.014

Carrizzo, A., Forte, M., Damato, A., Trimarco, V., Salzano, F., Bartolo, M.,... Vecchione, C. (2013). Antioxidant effects of resveratrol in cardiovascular, cerebral and metabolic diseases. Food and Chemical Toxicology, 61(1), 215-226. doi: 10.1016/j.fct.2013.07.021

Cézar, M. F., \& Souza, W. H. (2006). Avaliação e utilização da condição corporal como ferramenta de melhoria da reprodução e produção de ovinos e caprinos de corte. Anais da Reunião Anual da Sociedade Brasileira de Zootecnia, João Pessoa, PB, Brasil, 43.

Collodel, G., Federico, M. G., Geminiani, M., Martini, S., Bonechi, C., Rossi, C.,... Moretti, E. (2011). Effect of trans-resveratrol on induced oxidative stress in human sperm and in rat germinal cells. Reproductive Toxicology, 31(2), 239-246. doi: 10.1016/j.reprotox.2010.11.010

Delmas, D., Jannin, B., \& Latruffe, N. (2005). Resveratrol: Preventing properties against vascular alterations and ageing. Molecular Nutrition \& Food Research, 49(5), 377-395. doi: 10.1002/mnfr.200400098

Garcez, M. E., Branco, C. S., Lara, L. V., Pasqualotto, F. F., \& Salvador, M. (2010). Effects of resveratrol supplementation on cryopreservation medium of human semen. Fertility and Sterility, 94(6), 21182121. doi: 10.1016/j.fertnstert.2010.01.058

Guerra, M. M. P., Evans, G., \& Maxwell, W. M. C. (2004). Papel de oxidantes e antioxidantes na andrologia. Revista Brasileira de Reprodução Animal, 28(4), 187-195. Recovered from: http://www.cbra.org.br/ pages/publicacoes/rbra/download/v28n4.pdf

Henry, M., Neves, J. P., \& Jobim, M. I. M. (2013). Manual para exame andrológico e avaliação de sêmen animal. In M. Henry, J. P. Neves, \& M. I. M. Jobim, Caprinos (3a ed., pp. 39-42). Belo Horizonte: Colégio Brasileiro de Reprodução Animal.

Kao, S. H., Chao, H. T., Chen, H. W., Hwang, T. I. S., Liao, T. L., \& Wei, Y. H. (2008). Increase of oxidative stress in human sperm with lower motility. Fertility and Sterility, 89(5), 1183-1190. doi: 10. 1016/j. fertnstert.2007.05.029

Kasdallah-Grissa, A., Mornagui, B., Aouani, E., Hammami, M., May, M. E., Gharbi, N.,... El-Fazaâ, S. (2007). Resveratrol, a red wine polyphenol, attenuates ethanol-induced oxidative stress in rat liver. Life Sciences, 80(11), 1033-1039. doi: 10.1016/j.lfs.2006.11.044

Kennedy, J. H., Korn, N., \& Thurston, R. J. (2003). Prostaglandins levels in seminal plasma and sperm extracts of the domestic turkey, and the effects of cyclooxigenase inhibitors on sperm motility. Reproductive Biology and Endocrinology, 74(1), 1-7. doi: 10.1186/1477-7827-1-74

Longobardi, V., Zullo, G., Salzano, A., Canditiis, C., Cammarano, A., Luise, L.,... Gasparrini, B. (2017). Resveratrol prevents capacitation-like changes and improves in vitro fertilizing capability of buffalo frozen-thawed sperm. Theriogenology, 88(1), 1-8. doi: 10.1016/j.theriogenology.2016.09.046 
Memon, A. A., Wahid, H., Rosnina, Y., Goh, Y. M., Ebrahimi, M., \& Nadia, F. (2012). Effect of antioxidants on post thaw microscopic, oxidative stress parameter and fertility of Boer goat spermatozoa in Tris egg yolk glycerol extender. Animal Reproduction Science, 136(1-2), 55-60. doi: 10.1016/j. anireprosci.2012.10.020

Nickel, A., Kohlhaas, M., \& Maack, C. (2014). Mitochondrial reactive oxygen species production and elimination. Journal of Molecular and Cellular Cardiology, 73(1), 26-33. doi: 10.1016/j.yjmcc.2014. 03.011

Ourique, G. M., Finamor, I. A., Saccol, E. M. H., Riffel, A. P. K., Pês, T. S., Gutierrez, K.,... Barreto, K. P. (2013). Resveratrol improves sperm motility, prevents lipid peroxidation and enhances antioxidant defences in the testes of hyperthyroid rats. Reproductive Toxicology, 37(1), 31-39. doi: 10.1016/j. reprotox.2013.01.006

Peris, S. I., Bilodeau, J.-F., Dufour, M., \& Bailey, J. L. (2007). Impact of Cryopreservation and reactive oxygen species on DNA inetgrity, lipid peroxidation, and functional parameters in ram sperm. Molecular Reproduction and Development, 74(7), 878-892. doi: $10.1002 / \mathrm{mrd} .20686$

Pope, C. E., Zhang, Y. Z., \& Dresser, B. L. (1991). A simple staining method for valuating acrosomal status of cat spermatozoa. Journal of Zoo and Wildlife Medicine, 22(1), 87-95. Recovered from: https://www. jstor.org/stable/20095123

Purdy, P. H. (2006). A review on goat sperm cryopreservation. Small Ruminant Research, 63(3), 215-225. doi: 10.1016/j.smallrumres.2005.02.015

Resende, J., \& Weitze, K. F. (1987). Congelamento de sêmen de caprino com diluente TRIS modificado. Anais da Reunião Anual da Sociedade Brasileira de Zootecnia. Anais do Simpósio Sobre Reprodução Animal, Brasília, DF, Brasil, 24, 4.

Santiani, A., Evangelista, S., Sepúlveda, N., Risopatrón, J., Villegas, J., \& Sánchez, R. (2014). Addition of superoxide dismutase mimics during cooling process prevents oxidative stress and improves semen quality parameters in frozen/thawed ram spermatozoa. Theriogenology, 82(6), 884-889. doi: 10.1016/j. theriogenology.2014.07.002

Sarlós, P., Molnár, A., Kókai, M., Gábor, G., \& Rátky, J. (2002). Comparative evaluation of the effect of antioxidants in the conservation of ram semen. Acta Veterinaria Hungarica, 50(2), 235-245. doi: 10. 1556/AVet.50.2002.2.13
Sassi, N., Mattarei, A., Azzolini, M., Szabò, I., Paradisi, C., Zoratti, M., \& Biasutto, L. (2014). Cytotoxicity of mitochondria-targeted resveratrol derivatives: Interactions with respiratory chain complexes and ATP synthase. Biochimica et Biophysica Acta, 1837(10), 1781-1789. doi: 10.1016/j. bbabio.2014.06.010

Schmatz, R., Perreira, L. B., Stefanello, N., Mazzanti, C., Spanevello, R., Gutierres, J.,... Morsch, V. M. (2012). Effects of resveratrol on biomarkers of oxidative stress and on the activity of delta aminolevulinic acid dehydratase in liver and kidney of streptozotocin-induced diabetic rats. Biochimie, 94(2), 374-383. doi: 10.1016/j.biochi.2011.08.005

Shamsi, M. B., Kumar, R., Bhatt, A., Bamezai, R. N. K., Kumar, R., Gupta, N. P.,... Dada, R. (2008). Mitochondrial DNA Mutations in etiopathogenesis of male infertility. Indian Journal of Urology, 24(2), 150-154. doi: 10.4103/0970-1591.40606

Sicherle, C. C., Maia, M. S., Bicudo, S. D., Rodello, L., \& Gallego, I. C. (2011). Lipid peroxidation and generation of hydrogen peroxide in frozen-thawed ram semen supplemented with catalase or Trolox. Small Ruminant Research, 95(2-3), 144-149. doi: 10.1016/j.smallrumres.2010.10.011

Silva, E. C. B., Cajueiro, J. F. P., Silva, S. V., Soares, P. C., \& Guerra, M. M. P. (2012). Effect of antioxidants resveratrol and quercetin on in vitro viability of frozen ram sperm. Theriogenology, 77(8), 17221726. doi: 10.1016/j.theriogenology.2011.11.023

Statistical Analysis System Institute (2003). User's guide. Version 9.1.3 for Windows. Cary, NC: USA.

Stojanović, S., Sprinz, H., \& Brede, O. (2001). Efficiency and mechanism of the antioxidant action of transresveratrol and its analogues in the radical liposome oxidation. Archives of Biochemistry and Biophysics, 391(1), 79-89. doi: 10.1006/abbi.2001.2388

Talini, R., Kozicki, L. E., Gaievski, F. R., Polo, G., Lima, L. G. F., Santiago, J.,... Galan, T. G. B. (2019). Bovine semen thermoresistance tests and their correlation with pregnancy rates after fixedtime artificial insemination. Arquivo Brasileiro de Medicina Veterinária e Zootecnia, 71(6), 2085-2092. doi: 10.1590/ 1678-4162-10994

Watson, P. F. (2000). The causes of reduced fertility with cryopreserved semen. Animal Reproduction Science, 60-61(1), 481-492. doi: 10.1016/S03784320(00)00099-3

Xiang, L., Xiao, L., Wang, Y., Li, H., Huang, Z., \& He, X. (2014). Health benefits of wine: don't expect resveratrol too much. Food Chemistry, 156(1), 258263. doi: 10.1016/j.foodchem.2014.01.006 